\title{
Reoxidation of Cold and Hot Pressed Briquets Made of Reduced Ore Powder*
}

\author{
By Köji KAMIYA** and Minoru TANAKA**
}

\section{Synopsis}

Samples of reduced ore powder were prepared by reducing Hamersley hematite ore with pressurized hydrogen gas at about $900^{\circ} \mathrm{C}$ in a pilot plant for fluidized bed reduction. Cold and hot pressed briquets were produced from the reduced ore powder using a die at various temperatures.

The influences of compacting load at various temperatures on the crushing strength, density and rate of reoxidation with a mixture of oxygen and nitrogen gases at $250^{\circ}$ to $800^{\circ} \mathrm{C}$ were investigated.

The following results were obtained.

(1) To obtain briquets of high crushing strength and high density, it is desirable to use reduced ore powder above the reduction degree of $90 \%$.

(2) The maximum rate of reoxidation of briquets was observed at about $400^{\circ} \mathrm{C}$. This reason was assumed that the surface of particles reoxidized at temperature above $400^{\circ} \mathrm{C}$ was covered with thin and dense oxide film.

(3) Hot pressing at $500^{\circ}$ to $600^{\circ} \mathrm{C}$ was more favorable for high crushing strength of briquets than cold pressing under higher compacting load.

(4) The reoxidation of briquets obeyed a parabolic law and became slow with increase in the briquet density.

(5) Sintering of briquets at temperatures of $850^{\circ}$ to $1100^{\circ} \mathrm{C}$ for $4 \mathrm{hr}$ resulted in little increase in the density.

\section{Introduction}

Pellets and powder of reduced ores are produced from various processes of direct reduction. The reduced ore made by fluidized bed reduction processes, e.g., HIB process ${ }^{1)}$ and FIOR process, ${ }^{2)}$ is powdery.

The reduced ore powder is usually briquetted for use in steel making, because greater part of the powder, if introduced into a melting furnace, is immediately exhausted and the remainder is slagged and reoxidized before melting. The crushing strength plays an important role on the reoxidation and degradation of briquets during transportation and melting. Briquets having high crushing strength are suitable for steel making.

Iguchi and Inoue ${ }^{3,4)}$ reported that the initial rate of reoxidation of reduced iron powders was limited by

Table 1. Chemical composition of Hamersley ore. (wt\%)

\begin{tabular}{cccccc}
$\mathrm{T} . \mathrm{Fe}$ & $\mathrm{FeO}$ & $\mathrm{SiO}_{2}$ & $\mathrm{Al}_{2} \mathrm{O}_{3}$ & $\mathrm{P}$ & $\mathrm{S}$ \\
\hline 65.07 & 0.64 & 3.42 & 2.04 & 0.056 & 0.008 \\
\hline
\end{tabular}

the gaseous diffusion of oxidants and that the degree of reoxidation in a later stage was logarithmic with respect to time.

Brown et al. ${ }^{2)}$ reported that FIOR briquets did not reveal any significant reoxidation on exposure to weather for several months. In these briquets the effects of manufacturing condition on chemical and physical properties of briquets have been reported in no detail.

This report describes the effects of compacting pressure, density and crushing strength on the reoxidation of briquets produced with reduced ore powders from a $3 \mathrm{t} /$ day pilot plant ${ }^{5)}$ for fluidized bed reduction of Hamersley iron ore at $900^{\circ} \mathrm{C}$ under high pressure.

\section{Sample Material}

The Hamersley ore is used in this investigation. The chemical analysis of this ore is shown in Table 1. The ore was crushed, screened in the range of $16 \sim 115 \mathrm{mesh}$, and reduced with hydrogen of $8 \mathrm{~atm}$ at $900^{\circ} \mathrm{C}$ using a 2 stage fluidized bed reactor of 25 $\mathrm{cm}$ diameter. The degree of reduction was $97.17 \%$. The size distribution and the chemical composition of reduced ore powder are shown in Tables 2 and 3, respectively.

\section{Experimental Apparatus and Method}

\section{Manufacture of Briquets}

In this investigation, metallic dies were used for obtaining accurate dimention of briquets and for pressing the reduced powder by accurate compacting loads.

\section{Cold Briquetting}

$5 \mathrm{~g}$ of reduced ore powder was briquetted by an Amsler testing machine with metallic dies. The

Table 3. Chemical composition of reduced ore powder. $(\mathrm{wt} \%)$

\begin{tabular}{cccccc}
\hline T. Fe & M. Fe & $\mathrm{SiO}_{2}$ & $\mathrm{Al}_{2} \mathrm{O}_{3}$ & $\mathrm{P}$ & $\mathrm{S}$ \\
\hline 90.80 & $\mathbf{8 8 . 0 4}$ & 4.18 & 2.09 & 0.036 & 0.007 \\
\hline
\end{tabular}

Table 2. Size distribution of reduced ore powder.

\begin{tabular}{c|cccccccc}
\hline JIS mesh & +16 & $16 \sim 24$ & $24 \sim 32$ & $32 \sim 60$ & $60 \sim 80$ & $80 \sim 100$ & $100 \sim 115$ & -115 \\
\hline wt (\%) & 0.61 & 32.16 & 18.76 & 27.40 & 7.41 & 5.38 & 2.71 & 5.57 \\
\hline
\end{tabular}

Harmonic mean diameter : $0.395 \mathrm{~mm}$

* Originally published in Tetsu-to-Hagané, 65 (1979), 1517, in Japanese. English version received November 19, 1979.

** National Research Institute for Metals, Nakameguro, Meguro-ku, Tokyo 153. 
cylindrical briquets were of $1 \mathrm{~cm}^{2}$ cross sectional area and $1.1 \sim 1.4 \mathrm{~cm}$ height. The pressing was made using an upper punch and a lower punch, both free. Accordingly, a homogeneous load was added to the powder within a die.

A schematic diagram of a die and punches made of SKD 4 is shown in Fig. 1. The compacting time of samples by punches was about $1 \mathrm{~min}$. The inner surface of a die was coated with alcohol solution of zinc stearate as a lubricant.

\section{Hot Briquetting}

In a case of hot briquetting, the sample weight and the die dimension were the same as those in cold briquetting.

A schematic diagram of the hot pressing apparatus equipped with an oil press of $35 \mathrm{t}$ maximum load is shown in Fig. 2.

The die was heated to a desired temperature with an electric furnace. Nitrogen gas was continuously blown to this furnace in order to prevent the reoxidation of reduced powder.

The temperature of powder was measured by a thermocouple which was set at a distance of $0.1 \mathrm{~cm}$ from the inner surface of the die. After the temperature reached the desired temperature, reduced ore powder was fed into the die using a funnel. The temperature dropped down slightly due to the charge of reduced powder, and it was immediately raised again to the present value. After keeping at the given temperature for $5 \mathrm{~min}$, the hot reduced powder was pressed under various compacting loads for $1 \mathrm{~min}$.

The hot pressing time has considerable effects on the density of a briquet. Therefore, the relation between density and pressing time was investigated, as

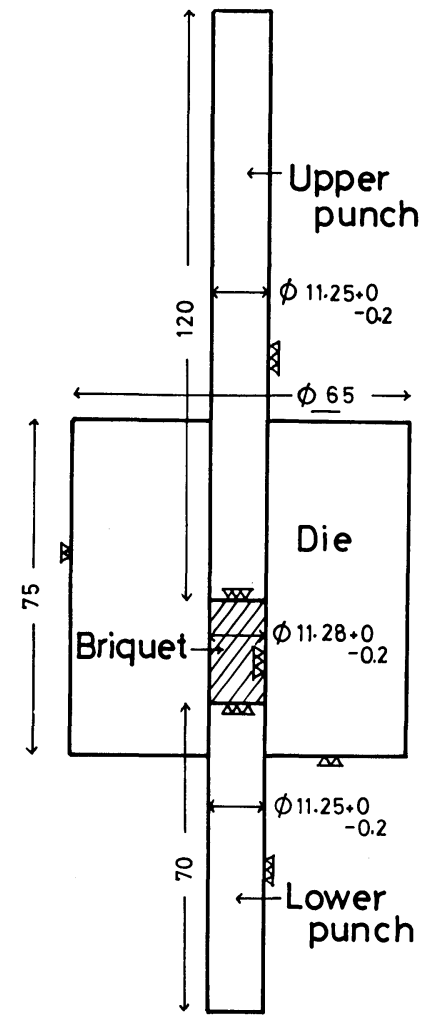

Fig. 1. Schematic diagram of die and punches. shown in Fig. 3. The density increased rapidly within $1 \mathrm{~min}$. Considering the productivity of a practical briquet machine as well as the density effect in Fig. 3, the pressing time of 1 min was determined.

In hot briquetting, reduced powder was uniformly pressed between upper and lower punches in a free die set on a Kaowool blanket. A hot briquet was cooled to room temperature in a chamber below the die in flowing nitrogen gas.

It is necessary to select carefully the materials of punches and a die, because these materials are used at high temperatures.

Asaji et al.$^{6)}$ used a graphite die and punches made of Co-alloy (S816) at $1150^{\circ} \mathrm{C}$ under $1.0 \mathrm{~kg} / \mathrm{cm}^{2}$. But, in this experiment for the briquetting of reduced powder at temperatures below $700^{\circ} \mathrm{C}$ under loads below $2 \mathrm{t} / \mathrm{cm}^{2}$, SKD 4 was used for the die and punches.

The sizes of the die and punches for hot briquetting were the same as those for cold briquetting. Graphite powder for forging was used as a lubricant for pressing.

\section{Measurement of Crushing Strength of a Briquet}

In the measurement of crushing strength of a briquet, it is desirable to test a large number of samples as used in the rattler test or the tumbler test. But, in this investigation $3 \sim 5$ pieces were used for

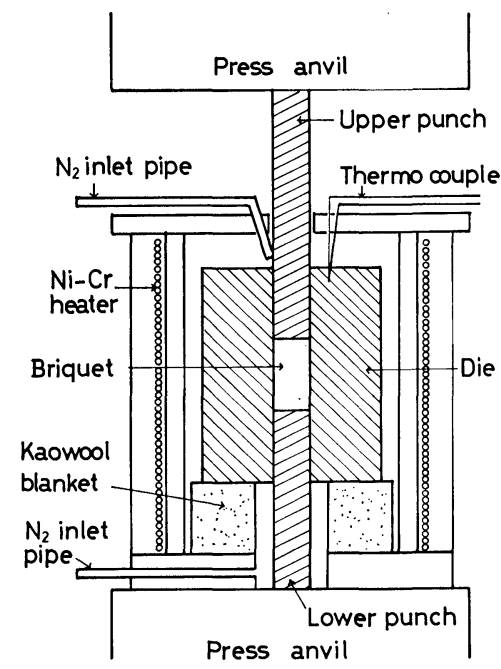

Fig. 2. Schematic cross section of hot pressing apparatus.

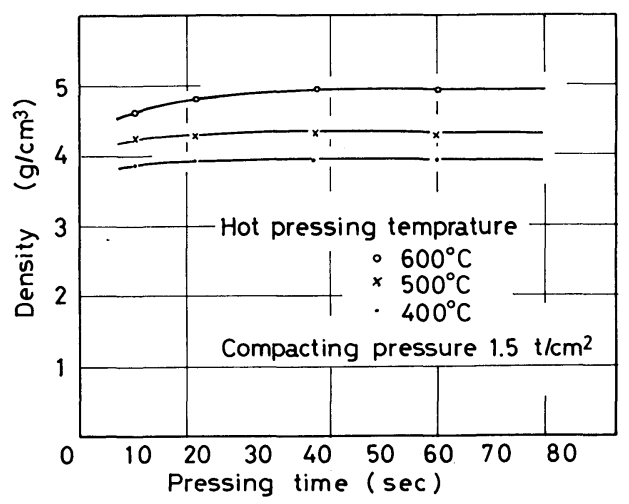

Fig. 3. Relation between density and pressing time in hot pressing. 
the average value of crushing strength, because of the difficulty of manufacturing many samples.

The crushing strength of a cylindrical briquet was very different between the axial direction and the radial direction, stronger in the former direction. In this study, the strength was measured in the radial direction.

\section{Reoxidizing Apparatus and Method}

It is important but takes a long time to measure the reoxidation rates of briquets in outdoor conditions. These measurements, however, are not reproducible, because of many unforeseen factors in nature. Therefore, reoxidation was performed with a gaseous mixture of $\mathrm{O}_{2}$ and $\mathrm{N}_{2}$ at various temperatures. The reoxidizing apparatus is shown in Fig. 4. A quartz reactor tube of about $3.4 \mathrm{~cm}$ inner diameter and 25 $\mathrm{cm}$ length has a pipe of about $0.8 \mathrm{~cm}$ inner diameter for the introduction of gases. A briquet that weighed accurately by a chemical balance was placed on a quartz boat and put into the reactor tube in which $\mathrm{N}_{2}$ gas flew. Finally, the reactor tube was put into an electric furnace. After the thermocouple set close to a briquet showed the given temperature in an atmosphere of $\mathrm{N}_{2}$, the gas mixture of $\mathrm{O}_{2}$ and $\mathrm{N}_{2}$ was introduced into the reactor tube in order to reoxidize the briquet. At the end of reoxidation, the briquet was cooled to room temperature in an atmosphere of $\mathrm{N}_{2}$ gas and the increase in weight of the briquet was measured.

In order to discuss the behavior of reoxidation of a briquet, the degree of reoxidation was calculated by the following equation.

$$
\text { Degree of reoxidation }(\%)=\frac{c-b}{\frac{b-a}{(1-e R)} \times e} \times 100 \ldots(1)
$$

where, $R$ : fractional degree of reduction of a reduced briquet (-)

$a$ : weight of a boat ( $\mathrm{g}$ )

$b$ : total weight of a boat and a briquet ( $\mathrm{g}$ )

$c$ : total weight of a boat and a reoxidized briquet $(\mathrm{g})$

$e:$ reducible oxygen contained in unreduced ore (g-oxygen/g-ore)

In this experiment, it was found that briquet is reoxidized in a topochemical manner, but as described before, the height of a briquet was different

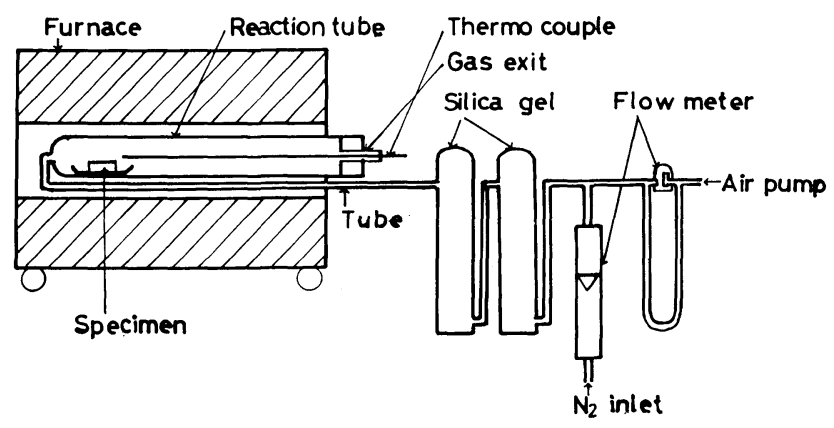

Fig. 4. Schematic diagram of reoxidizing apparatus. at various compacting loads. Therefore, the reoxidation rate was calculated by Eq. (2), not from the weight change of a briquet, considering the difference of surface area of a briquet.

$$
O=1-\frac{r^{2}\left(\alpha r_{0}-r_{0}+r\right)}{\alpha r_{0}^{3}}
$$

where, $r_{0}$ : radius of a briquet $(\mathrm{cm})$

$\alpha$ : ratio of the height to the diameter of a briquet

$r$ : radius of unreoxidized part at the reoxidized time of $t$

$O:$ degree of reoxidation (-)

Now, if $f=\left(r_{0}-r\right) / r_{0}$, Eq. (3) was obtained.

$$
O=1-\frac{(1-f)^{2}(\alpha-f)}{\alpha}
$$

This equation shows a relation between the fractional thickness $f$ of reoxidized layers and degree of reoxidation of a cylindrical briquet under various compacting loads. Using Eq. (3), the time dependence of $f$ was investigated.

The reoxidation was performed with a gas mixture of $\mathrm{O}_{2}$ and $\mathrm{N}_{2}$ at a flow rate of 200 to $1000 \mathrm{ml} / \mathrm{min}$ at $400^{\circ} \mathrm{C}$, at which the reoxidation rate was maximum. These results are shown in Fig. 5, indicating that the rate of reoxidation has little dependence on the flow rate in the range of 200 to $1000 \mathrm{ml} / \mathrm{min}$. Therefore, all the other experiments were carried out at a flow rate of $500 \mathrm{ml} / \mathrm{min}$.

In the reoxidizing experiments, the temperature control of briquet surface has to be precise, because the reoxidizing reaction is exothermic. The temperatures on the surface and about $0.2 \mathrm{~cm}$ below the surface were measured using a briquet cold pressed under the load of $3 \mathrm{t} / \mathrm{cm}^{2}$. The results obtained are shown in Fig. 6. As is clear from this figure, the surface temperature was higher than the subsurface temperature. This phenomenon shows that the reoxidation starts at the surface of a briquet. When reoxidized by a gas mixture of $20 \% \mathrm{O}_{2}-80 \% \mathrm{~N}_{2}$, the surface temperature was about $55^{\circ} \mathrm{C}$ higher and the subsurface temperature was about $30^{\circ} \mathrm{C}$ higher than the given reoxidation temperature. In case of a gas mixture containing $4 \% \mathrm{O}_{2}$, the increase in the surface tem-

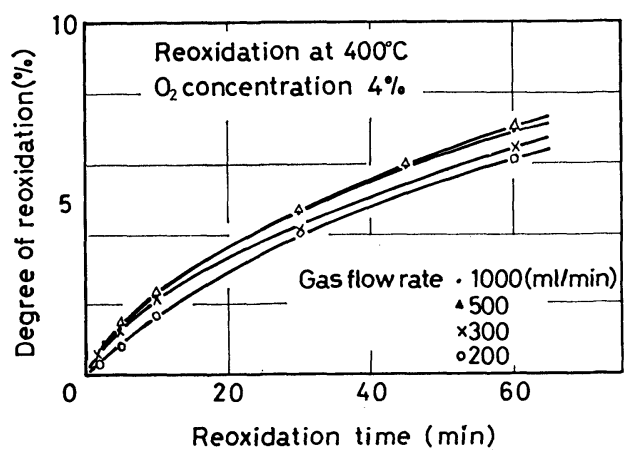

Fig. 5. Time dependence of degree of reoxidation at various gas flow rates. (Degree of reduction: 97.17\%, Hamersley reduced powder) 


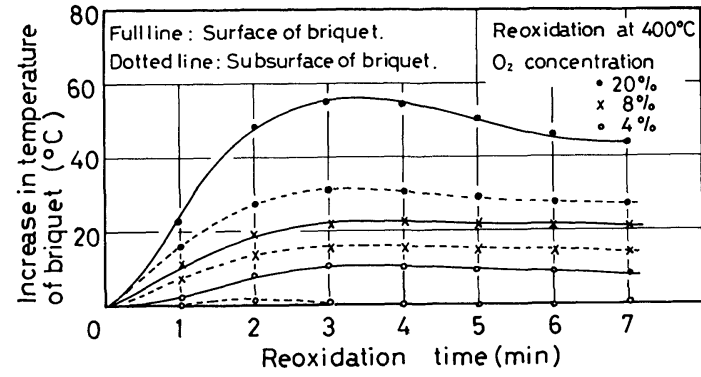

Fig. 6. Increase in temperature of briquets during reoxidizing at various oxygen gas concentration. (Degree of reduction: $97.17 \%$, Hamersley reduced powder)

perature was within $10^{\circ} \mathrm{C}$, and it was within $2^{\circ} \mathrm{C}$ below the surface. From these results, all the other experiments were performed with a gas mixture of $4 \% \mathrm{O}_{2}-96 \% \mathrm{~N}_{2}$ at a flow of $500 \mathrm{ml} / \mathrm{min}$.

\section{Results and Discussion}

1. Relation between Briquet Density and Compacting Load

In general, a large compacting load is necessary for high crushing strength and high density of briquets, but the magnitude of a load is limited by the material of a metallic die and punches. Under these considerations, as described before, SKD 4 was used as the material of a die and punches in all cases.

The relation between density of briquet and compacting load at various temperatures are shown in Fig. 7.

In cold briquetting, the density increased with increasing the load, but above the load of $3 \mathrm{t} / \mathrm{cm}^{2}$ the influence of load on density tended to decrease slightly. In hot briquetting, the dependency of compacting loads on the density of briquet became large with increasing temperature during the briquetting.

As a result, a briquet of density of $5 \mathrm{~g} / \mathrm{cm}^{3}$ was obtained at a load of $7 \mathrm{t} / \mathrm{cm}^{2}$ in cold briquetting, and was obtained at only $2 \mathrm{t} / \mathrm{cm}^{2}$ in hot briquetting.

\section{The Crushing Strength of Briquets}

The crushing strength of briquets was influenced by the compacting load, in addition to the property of particles such as plasticity, shape and size distribution of particles.

In this investigation, the effect of compacting pressure on the crushing strength of cold and hot briquets was investigated using reduced powder with the same properties.

The results for cold briquets were shown in Fig. 8 . As is evident from this figure, the crushing strength increased with the load in the range below $5 \mathrm{t} / \mathrm{cm}^{2}$, but when loads increased beyond $5 \mathrm{t} / \mathrm{cm}^{2}$, the increase in the crushing strength became small. In contrast, the crushing strength of hot briquets, shown in Fig. 9 , increased rapidly with temperature during a briquetting process. In hot briquetting, high strength briquets were obtained at lower loads than in cold briquetting.

Photograph 1 shows the axial section of hot bri-

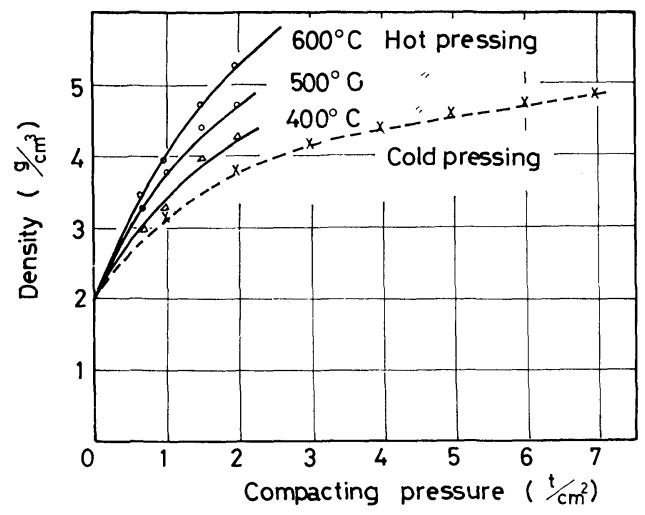

Fig. 7. Relation between density of briquets and compacting pressure at various pressing temperatures. (Degree of reduction: $97.17 \%$, Hamersley reduced powder)

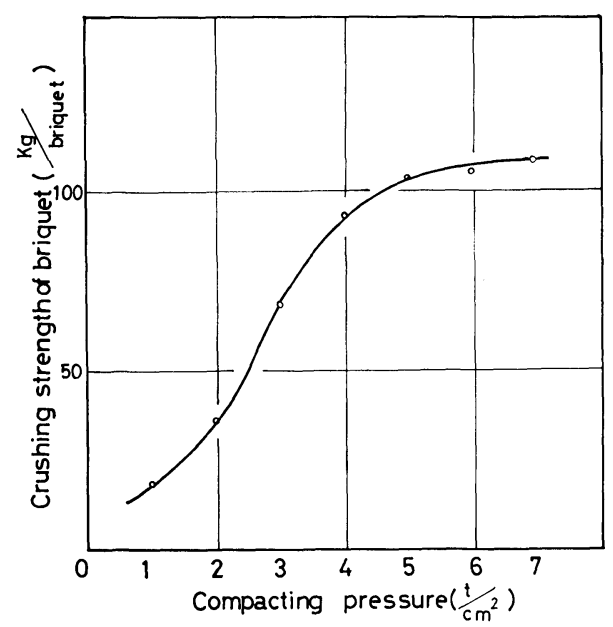

Fig. 8. Effect of compacting pressure on crushing strength of cold pressed briquets. (Degree of reduction: $97.17 \%$, Hamersley reduced powder)

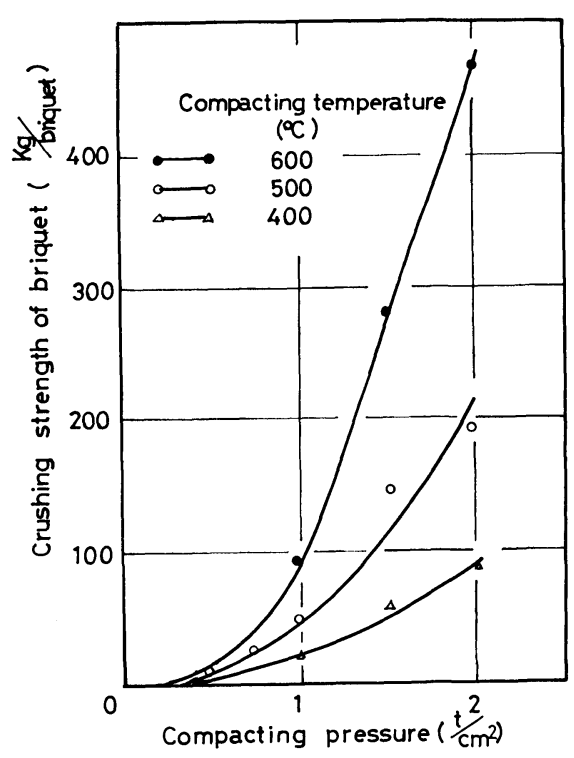

Fig. 9. Effect of compacting pressure on crushing strength of hot pressed briquets. (Degree of reduction: $97.17 \%$, Hamersley reduced powder) 

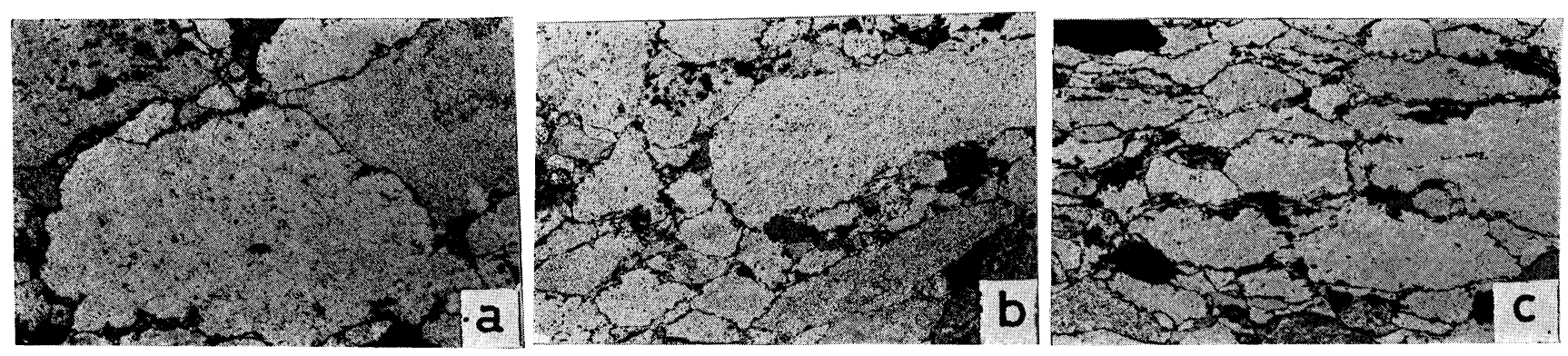

(a) Compacting pressure at $1 \mathrm{t} / \mathrm{cm}^{2}$, (b) Compacting pressure at $1.5 \mathrm{t} / \mathrm{cm}^{2}$, (c) Compacting pressure at $2 \mathrm{t} / \mathrm{cm}^{2}$

Photo. 1. Effect of compacting pressure on deformation of ore particles at $600^{\circ} \mathrm{C}$ hot pressing. $(\times 70)(\times 4 / 5)$

quets at $600^{\circ} \mathrm{C}$. It was observed that the grain size of briquets became small and the deformation of particles became large with an increase in compacting load.

All results that have been described above were obtained in the investigation using Hamersley ore powder of $97.17 \%$ reduction.

Figure 10 shows the effect of the reduction degree for cold briquets $\left(5 \mathrm{t} / \mathrm{cm}^{2}\right)$ and hot briquets $\left(600^{\circ} \mathrm{G}\right.$, $\left.2 \mathrm{t} / \mathrm{cm}^{2}\right)$.

The density of these briquets was almost the same. In cold briquetting, the crushing strength increased gradually with increasing degree of reduction. In hot briquetting, the crushing strength increase was faster, in particular extremely steep above $90 \%$ reduction. A reason for the increase is considered that particles containing a large amount of metallic $\mathrm{Fe}$ were more plastic than particles of low metallic Fe content. As found from Fig. 10, the linearity holds between the reduction and the density.

The density of hot briquets at $2 \mathrm{t} / \mathrm{cm}^{2}$ and $600^{\circ} \mathrm{C}$ was higher than that of cold briquets at $5 \mathrm{t} / \mathrm{cm}^{2}$ in the range above $80 \%$ reduction.

\section{Reoxidation Behavior of Briquets}

As described in III.3., the behavior of reoxidation of reduced briquets in outdoor conditions is of important. However, there are many difficult problems in this experiment. Therefore, reoxidation tests for accurate and reproducible results were performed with a gas mixture of $\mathrm{O}_{2}$ and $\mathrm{N}_{2}$ in the temperature range of $200^{\circ}$ to $800^{\circ} \mathrm{C}$.

\section{Reoxidation of Cold Briquets}

The effect of temperature on reoxidation degree of cold briquets oxidized for 60 min with a gas mixture of $4 \% \mathrm{O}_{2}-96 \% \mathrm{~N}_{2}$ is shown in Fig. 11. As is clear from this figure, the reoxidation degree showed the maximum value at $400^{\circ} \mathrm{C}$.

The existence of a maximum value at a certain temperature has been reported by Iguchi et al. ${ }^{\mathbf{3})}$ and Kasahara $e t$ al. ${ }^{8)}$ In general, the oxidation rate of steel in air increases with increasing temperature. The existence of a maximum value is considered to be due to the increase of porosities and surface area of briquets during reoxidation. The microstructure of about $10 \%$ reoxidized briquets at $400^{\circ}$ and $600^{\circ} \mathrm{C}$ was investigated as shown in Photo. 2.

At $400^{\circ} \mathrm{C}$, reoxidation proceeded into inner part

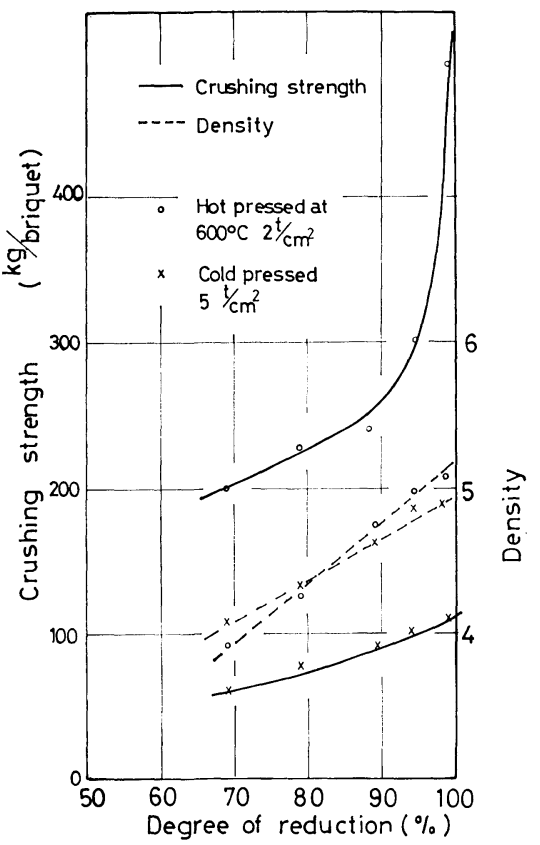

Fig. 10. Effects of degree of reduction on crushing strength and density of briquets. (Hamersley reduced powder)

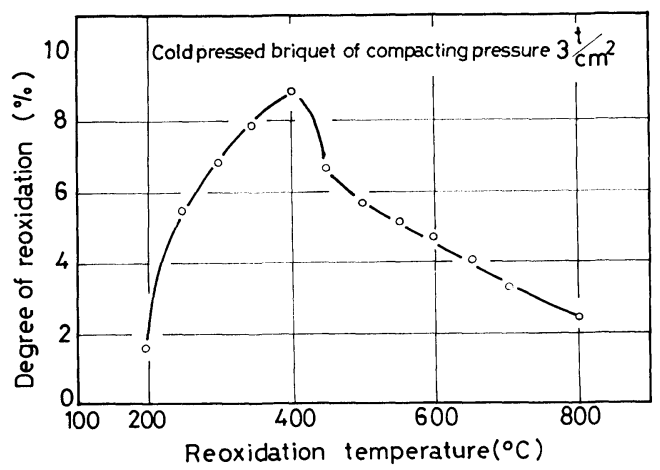

Fig. 11. Effect of reoxidation temperature on reoxidation degree of cold pressed briquets. (Degree of reduction: $97.17 \%$, Hamersley reduced powder)

of a particle.

At $600^{\circ} \mathrm{C}$, however, microscopic observation and $\mathrm{X}$-ray diffraction of the reoxidized surface showed that all the surface area was covered with thin and dense oxide films, indicating that reoxidation did not proceed into inner part of particles.

A relation between reoxidation rate and tempera- 

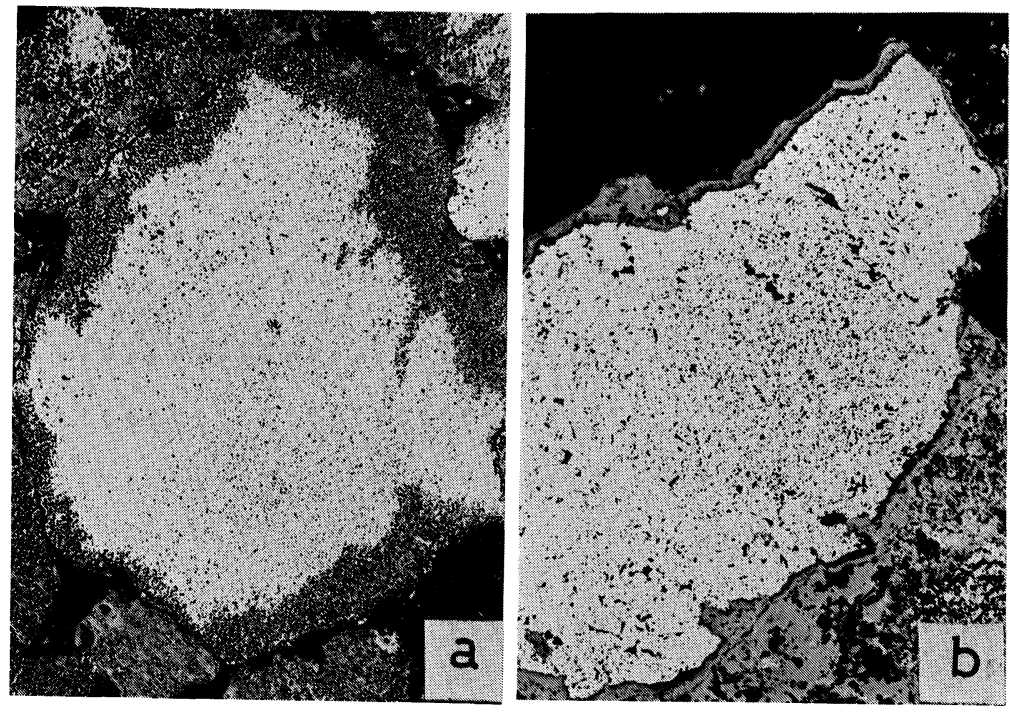

(a) Reoxidation with $\mathrm{O}_{2} \quad 4 \%-\mathrm{N}_{2} \quad 96 \%$ mixed gas at $400^{\circ} \mathrm{C}$

(b) Reoxidation with $\mathrm{O}_{2} \quad 4 \%-\mathrm{N}_{2} \quad 96 \%$ mixed gas at $600^{\circ} \mathrm{C}$

Photo. 2. Microstructures of reoxidized ore particles. $(\times 100)(\times 5 / 6)$

ture was investigated under the condition of rapid change between two temperatures $\left(400^{\circ}\right.$ and $\left.600^{\circ} \mathrm{C}\right)$ during reoxidation of briquets. The results are shown in Fig. 12. A reoxidation curve (1) in this figure shows an experiment in which cold briquets pressed by a load of $3 \mathrm{t} / \mathrm{cm}^{2}$ were first reoxidized at $400^{\circ} \mathrm{C}$ for $1 \mathrm{hr}$ with a gas mixture of $4 \% \mathrm{O}_{2}-96 \% \mathrm{~N}_{2}$ and then the temperature was raised to $600^{\circ} \mathrm{C}$. Curve (1) was similar to that for simple reoxidation at $400^{\circ} \mathrm{G}$. For curve (2), after reoxidation at $600^{\circ} \mathrm{C}$ for $1 \mathrm{hr}$, the temperature of the partially reoxidized briquet was lowered to $400^{\circ} \mathrm{C}$ with the gas composition unchanged. In this case, the rate of reoxidation was increased in spite of decrease in temperature from $600^{\circ}$ to $400^{\circ} \mathrm{G}$.

As described in a report of Sugiyama et al.,9) it would be expected that the $\mathrm{FeO}$ layer formed at the surface of particles at $600^{\circ} \mathrm{C}$ decomposed to $\mathrm{Fe}_{3} \mathrm{O}_{4}$ and $\mathrm{Fe}$ at $400^{\circ} \mathrm{C}$, the protecting film thereby being destroyed.

Relations between $\sqrt{t}$ and $f$ at three reoxidation temperatures $\left(250^{\circ} \mathrm{C}, 400^{\circ} \mathrm{C}\right.$ and $\left.600^{\circ} \mathrm{C}\right)$ for cold briquets pressed under various loads $\left(1,3\right.$ and $\left.5 \mathrm{t} / \mathrm{cm}^{2}\right)$ are shown in Fig. 13. In this figure, it became clear that rates of reoxidation followed the parabolic law and decreased with increasing the load.

The behavior of reoxidation of a high density briquet and a low density briquet is shown in Photo. 3. From this photo, it became clear that the reoxidized thin layer was formed mainly at the surface of a high density briquet, while in a low density briquet the surface of particles in the vicinity of the briquet surface was reoxidized. Therefore, it may be considered that a briquet is reoxidized in topochemical manner.

\section{Reoxidation of Hot Briquets}

Hot briquets were reoxidized with a gas mixture of $4 \% \mathrm{O}_{2}-96 \% \mathrm{~N}_{2}$ at $400^{\circ} \mathrm{C}$. At this temperature the maximum rate of reoxidation of cold briquets was obtained.

Results on briquets pressed at $400^{\circ}, 500^{\circ}$ and $600^{\circ} \mathrm{C}$ are shown in Fig. 14. In this case, the rates of reoxidation followed the parabolic law. In Fig. 15, the rate constants of reoxidation $K$ were obtained from

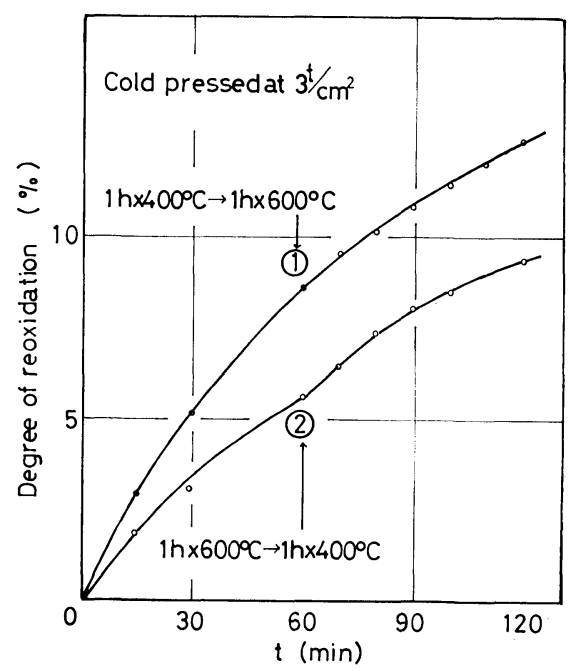

Fig. 12. Effect of abrupt temperature change on reoxidation behavior.

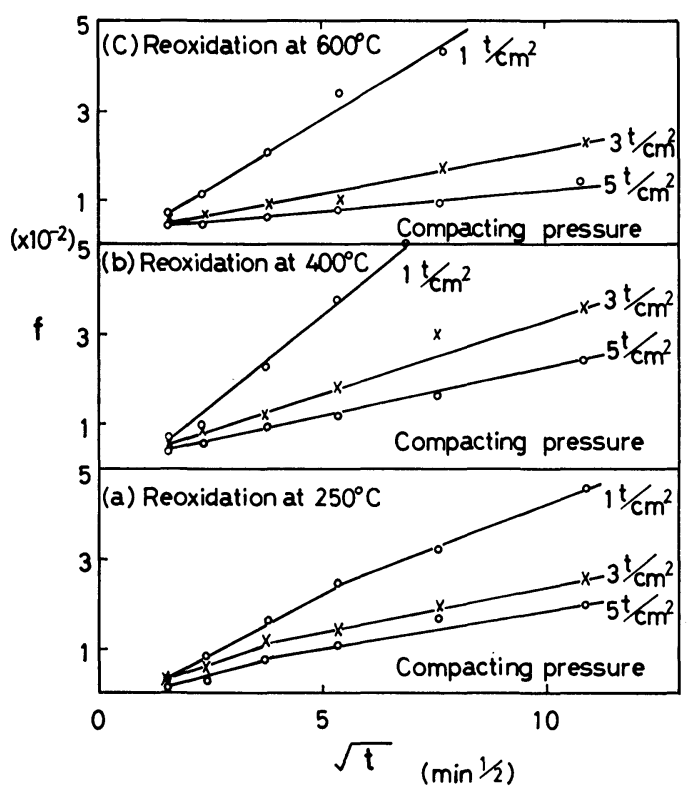

Fig. 13. Relation between square root of reoxidizing time and fractional thickness of reoxidized film on cold pressed briquets. 

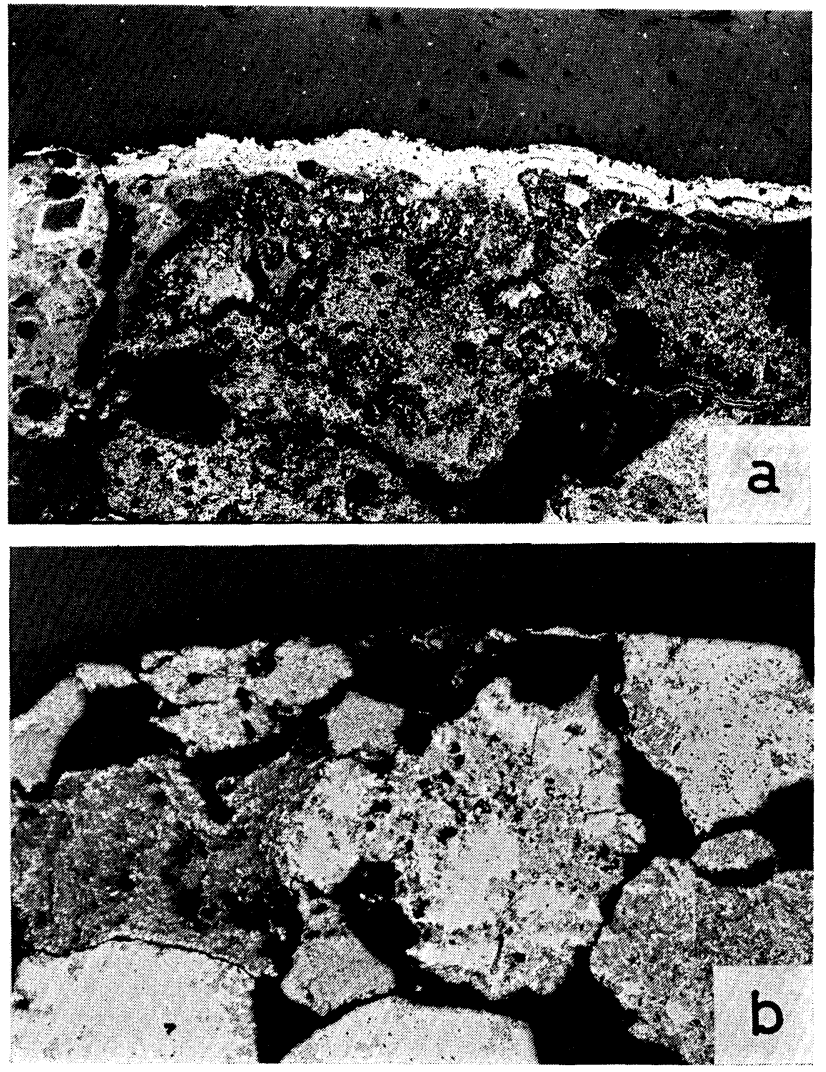

(a) Reoxidized high density briquet

(b) Reoxidized low density briquet

Photo. 3. Microstructures of reoxidized high density briquet and low density briquet. $(\times 50)(\times 4 / 5)$

the slopes of straight lines in Fig. 14, showing a linear decrease with increasing density of briquets.

The rate constant $K$ is expressed in terms of the density of briquets as follows.

$$
\kappa=(-3 D+17.2) \times 10^{-3}
$$

This expression agrees with the microscopic observation in Photo. 3 that the effective surface area reoxidized in a unit surface of a briquet decreases with increase in the density of a briquet.

These results were independent of the briquetting process such as a hot briquetting or cold one. From this figure, it is found that the reoxidation would not practically occur for $D \doteqdot 5.7$ (the theoretical density was about 7.4). Therefore, the high resistance of FIOR briquet to reoxidation could be attributed to its high density.

\section{The Effect of Sintering on Increase in Density}

It became clear that the increase in the briquet density was effective for protecting the reoxidation. Therefore, new experiments were performed to investigate the effect of sintering on the density of briquets. Hot briquets $\left(600^{\circ} \mathrm{C}, 1.5 \mathrm{t} / \mathrm{cm}^{2}\right)$ and cold briquets $\left(3 \mathrm{t} / \mathrm{cm}^{2}\right)$ were sintered at $850^{\circ}, 950^{\circ}$ and $1100^{\circ} \mathrm{C}$ for $4 \mathrm{hr}$ in $\mathrm{N}_{2}$ gas. The results were shown in Fig. 16. As is evident from this figure, the density of briquets increased with sintering time and with temperature. The increase of density was about $8 \%$ at $1100^{\circ} \mathrm{C}$ in

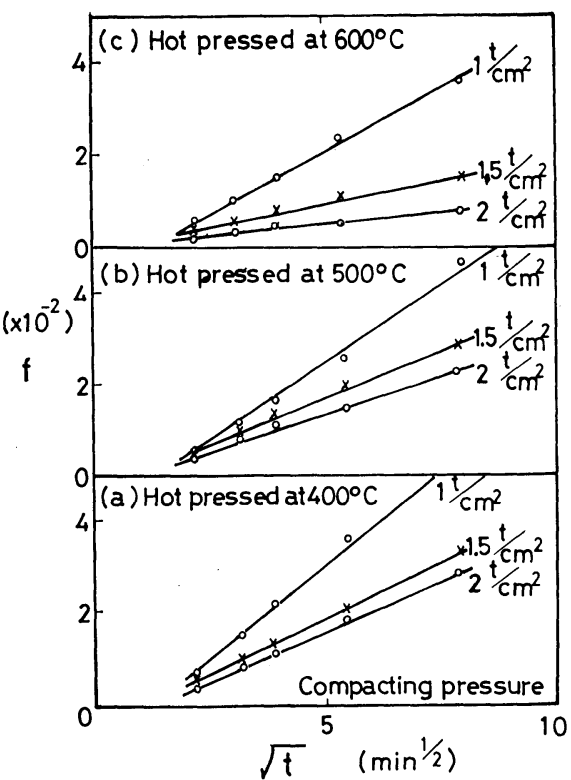

Fig. 14. Relation between square root of reoxidizing time and fractional thickness of reoxidized film on hot pressed briquets.

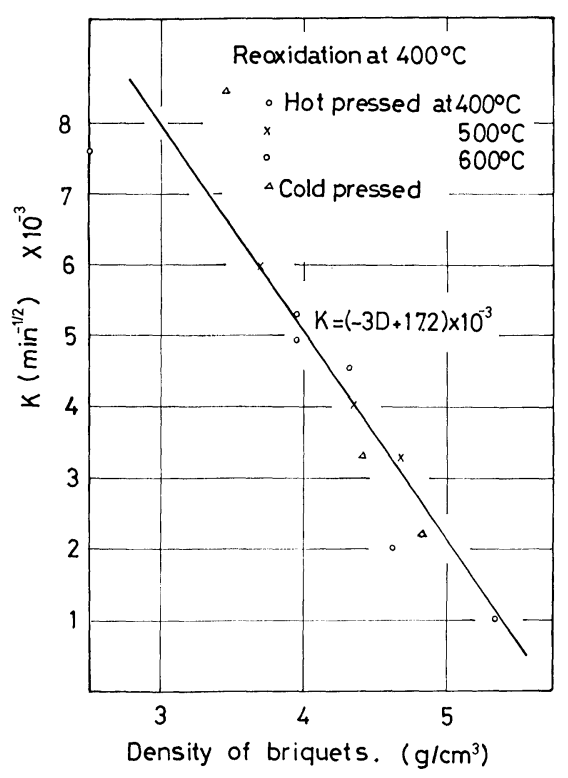

Fig. 15. Relation between rate constant of reoxidation and density of briquets. (Degree of reduction: $97.17 \%$, Hamersley reduced powder)

$4 \mathrm{hr}$. In general, cold pressed briquets have larger increase of density then hot pressed briquets, because hot pressed briquets had a higher density before sintering.

Figure 17 shows the relation between the crushing strength of sintered briquets and sintering temperature. The crushing strength of sintered briquets increased rapidly above $950^{\circ} \mathrm{G}$. From results mentioned above, it is found that the increases in the density and the crushing strength of briquets by sintering are unfavorable, because high temperatures and long time are necessary for the sintering of briquets. 


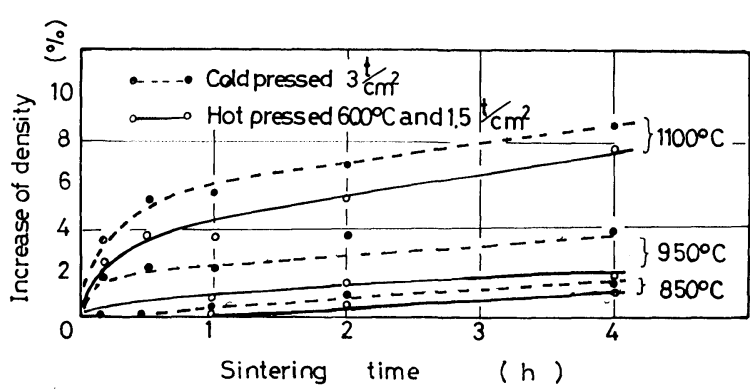

Fig. 16. Effect of sintering time on increase of density of briquets at various temperatures. (Degree of reduction: $97.17 \%$, Hamersley reduced powder)

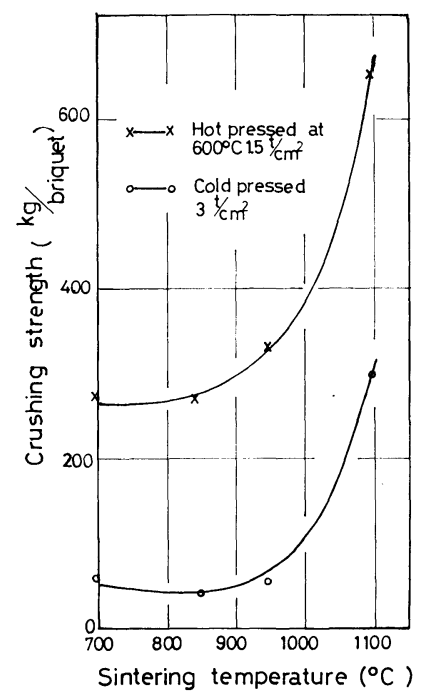

Fig. 17. Effect of sintering temperature on crushing strength of briquets. (Degree of reduction: $97.17 \%$, Hamersley reduced powder)

\section{Conclusions}

Reduced ore powder was prepared by reducing Hamersley hematite ore with pressurized hydrogen gas at about $900^{\circ} \mathrm{C}$ in a pilot plant for fluidized bed reduction. Cold and hot pressed briquets were produced from the reduced ore powder using a die at various temperatures.

The following results were obtained.

(1) To obtain briquets of high crushing strength and high density, it is desirable to use reduced ore powder above the reduction degree of $90 \%$.

(2) The maximum rate of reoxidation of briquets was observed at about $400^{\circ} \mathrm{C}$. This reason was assumed that the surface of particles reoxidized at temperature above $400^{\circ} \mathrm{G}$ was covered with thin and dense oxide film.

(3) Hot pressing at $500^{\circ}$ to $600^{\circ} \mathrm{C}$ was more favorable for high crushing strength of briquets than cold pressing under higher compacting load.

(4) The reoxidation of briquets obeyed a parabolic law and became slow with increase in the briquet density.

(5) Sintering of briquets at temperatures of $850^{\circ}$ to $1100^{\circ} \mathrm{G}$ for $4 \mathrm{hr}$ resulted in little increase in the density.

\section{REFERENCES}

1) T. F. Reed, J. G. Agarwal and E. H. Shipley: J. Metals, 12 (1960), 317.

2) J. W. Brown, D. L. Campbell, A. L. Saxton and J. W. Carr, Jr: J. Metals, 18 (1966), 237.

3) Y. Iguchi and M. Inoue: Tetsu-to-Hagané, 56 (1970), 507.

4) Y. Iguchi and M. Inoue: Tetsu-to-Hagané, 56 (1970), 671.

5) I. Morinaka, K. Kamiya, K. Sakuraya, N. Kitahara, M. Ozawa and M. Tanaka: Trans. ISIJ, 20 (1980), 177.

6) T. Asaji, M. Yoshikawa and S. Kanzaki: J. Japan Soc. Precision Eng., 41 (1975), 1001.

7) Mechanism of Sintering, ed. by The Japan Soc. Powder and Powder Metallurgy, Nikkankogyo-Shinbunsha, Tokyo, (1964), 31.

8) N. Kasaoka and Y. Murata: Kogyokagaku Zasshi, 64 (1961), 978.

9) M. Sugiyama: Heating and Oxidizing of Metals, Seibundo-Shinkosha, Tokyo, (1955), 61. 